\title{
Genealogical Counternarratives in the Writings of Mary Carey
}

\author{
MICHELLE M. DOWD \\ University of North Carolina, Greensboro
}

Mary Carey (ca. 1609-80) is best known to scholars for her lyric poetry. Very little is known with certainty about Carey, since many of the autobiographical "facts" of her life derive from her own writings, but we do know that she was the daughter and heir of Sir John Jackson of Berwick upon Tweed and that she was married twice, first to Pelham Carey (ca. 1612-1642/3), a younger son of Henry Carey, first earl of Dover, and after his death to George Payler (d. in or before 1678), paymaster of the garrison at Berwick from 1639 to $1642 .{ }^{1}$ Carey had seven children with Payler (in addition to one child who survived from her first marriage), but five of these children died in infancy, including one apparent miscarriage. Carey's biography, such as it is, has inflected critical assessments of her writing. Child loss and miscarriage are themes that pervade much of Carey's poetry, and these tropes are particularly notable in the occasional lyrics that seem to comment directly on the deaths of five of her children during her second marriage. Indeed, recent criticism on Carey has focused on her poetry as emblematic of the genre of elegy and specifically the subgenre of child loss poetry. ${ }^{2}$ Such anal-

I would like to thank Julie Eckerle, Erica Longfellow, Lisa Schnell, Sharon Seelig, Richard Strier, the participants at the 2007 Princeton Symposium on Early Modern Women's Autobiography and the 2009 annual conference of the Renaissance Society of America, and the anonymous readers for Modern Philology for their helpful comments on earlier versions of this essay.

1. Sara H. Mendelson, "Mary Carey (b. c. 1609, d. in or after 1680)," in Oxford Dictionary of National Biography (Oxford University Press, 2004), http://www.oxforddnb.com/view/article $/ 45811$.

2. See Pamela Hammons, "Despised Creatures: The Illusion of Maternal Self-Effacement in Seventeenth-Century Child Loss Poetry," ELH 66 (1999): 25-49; Donna J. Long, "It is a lovely bonne I make to thee': Mary Carey's 'abortive Birth' as Recuperative Religious Lyric," in Discovering and $(R e)$ Covering the Seventeenth Century Religious Lyric, ed. Eugene R. Cunnar and Jeffrey Johnson (Pittsburgh: Duquesne University Press, 2001), 248-72; Raymond A. Anselment, "AA heart terrifying Sorrow': An Occasional Piece on Poetry of Miscarriage," Papers on Lan-

(C) 2012 by The University of Chicago. All rights reserved. 0026-8232/2012/10904-0002\$10.00 
yses have productively illuminated the formal structures that translate personal loss into poetic text, demonstrating the degree to which the category of the personal is historically constituted through textual discourse.

However, focusing on Carey's lyrics as maternal elegies occludes discussion of genres and techniques that connect her work to cultural narratives beyond parental loss or personal suffering. The elegy, in other words, is only one genre in Carey's oeuvre. Though her child loss poems are those for which Carey is most often remembered, they exist in manuscript form alongside other prose and verse meditations, including an autobiographical conversion narrative in the form of a dialogue "Betwixt the Soul and the Body." The presentation manuscript of Carey's writing housed in the Bodleian Library (MS Rawlinson D. 1308) comprises over one hundred folios and includes texts dating from 1647 to 1657 . The first ninety-four folios consist entirely of prose, while the remaining pages feature a mix of verse elegy and prose meditation. ${ }^{3}$ By separating out Carey's lyrics from the prose genres that comprise the majority of her manuscript, critics and scholars neglect an important context for understanding the range of rhetorical strategies Carey used to interrogate personal loss and maternal agency in her writings. Attending to the formal variety displayed in Carey's manuscript can help us to elucidate the "discursive contours of gendered identity" in the period and better understand the complex ways in which personal narratives intersected with England's rich literary tradition. ${ }^{4}$ In particular, such

guage and Literature 33 (1997): 13-45; Elizabeth Clarke, "AA heart terrifying Sorrow': The Deaths of Children in Seventeenth-Century Women's Manuscript Journals," in Representations of Childhood Death, ed. Gillian Avery and Kimberley Reynolds (Basingstoke: Macmillan, 2000), 65-86; and Lisa J. Schnell, "'Lett me not pyne for poverty': Maternal Elegy in Early Modern England," in The Oxford Handbook of the Elegy, ed. Karen Weisman (Oxford University Press, 2010), 481-97. Kelly M. Neill places Carey in the context of both seventeenth-century female prophets and the metaphysical poets in “'Doe as I Have Done': Mary Carey's Reciprocal Relationship with the Divine” (MA thesis, University of North Carolina, Greensboro, 2006).

3. Carey's autograph manuscript book is in the private collection of the Meynell family. Bodleian Library MS Rawlinson D. 1308 is a presentation copy of the autograph manuscript made by Charles Hutton in 1681. Carey's writings appear on fols. 1r-117v, while the second part of the manuscript (fols. 118r-166v) contains the prose memoir of Sir Thomas Fairfax. Carey's "A Dialogue Betwixt the Soul and the Body" appears on fols. 7r-94v of the Bodleian manuscript. All further references to Carey's prose writings are taken from the Bodleian manuscript and will be given parenthetically in the text. Selected prose and verse excerpts from the manuscript (liberally edited and rearranged) are also available in a 1918 edition printed by Sir Francis Meynell, Meditations from the Note Book of Mary Carey, 1649-1657(Westminster).

4. See Genre and Women's Life Writing in Early Modern England, ed. Michelle M. Dowd and Julie A. Eckerle (Aldershot: Ashgate, 2007), 2. As a method for reading women's writing more generally, this approach has the added benefit of shifting focus away from the exceptional or oppositional aspects of women's textual lives (e.g., their resistance to male authority) and considering instead their embeddedness within a range of discursive contexts, including the orthodox as well as the more radical. On this point, see Erica Longfellow, Women and Religious Writing in Early Modern England (Cambridge University Press, 2004), 59-91. 
an approach reveals the extent to which Carey's manuscript is part of a vibrant historical conversation about maternal authority-not only in personal or familial terms but also in terms of its significance to a broader understanding of genealogy. Locating her child loss elegies within this larger textual framework, I offer an approach to Carey that not only considers her prose writings alongside her poetry but demonstrates how this body of writing uses providential narratives to engage with significant discourses about patrilineality, succession, and lineage in early modern England.

Hereditary succession in England was governed, particularly at elite levels of society, by the doctrine of male primogeniture. Although there were numerous legal and practical exceptions to this doctrine, the cultural ideology that sustained it privileged an unbroken line of male succession and produced difficulties for families unable to produce a suitable heir. Furthermore, by the time of Carey's writing at midcentury, the development of the strict settlement was reinforcing the practice of primogeniture by greatly limiting the ways in which parents could allocate their estates. ${ }^{5}$ The strict settlement would not become standard practice until the end of the century, but it was nevertheless a dominant trend in the period that gradually transformed an already restrictive legal system into an even more rigid one. These changes effectively raised the stakes on the production of a male heir.

The legal and economic conditions that governed succession in the seventeenth century, however, did not exist in a vacuum but were intimately tied to spiritual belief, especially for English Protestants. ${ }^{6}$ For followers of Calvinist teaching, barrenness and the death of child, for instance, were understood in a providentialist framework as events used by God to communicate with the elect and eventually bring them to salvation. It thus became the "duty of the pious to decipher and register... these divine tokens."7 The loss of children could be read as a reminder of sinfulness and a call to rely solely on God rather than on earthly things, but it could also be interpreted in more dire terms as a form a divine punishment, the corollary to the idea that children were God's providential blessing. ${ }^{8}$ As Phyllis Mack

5. On the strict settlement, see Amy Louise Erickson, Women and Property in Early Modern England (London: Routledge, 1993), esp. 102-3; Eileen Spring, Law, Land, and Family: Aristocratic Inheritance in England, 1300 to 1800 (Chapel Hill: University of North Carolina Press, 1993); and Lawrence Stone, The Crisis of the Aristocracy, 1558-1641 (Oxford University Press, 1967), 62-95.

6. See Valerie Forman, Tragicomic Redemptions: Global Economics and the Early Modern English Stage (Philadelphia: University of Pennsylvania Press, 2008), esp. 11.

7. See Alexandra Walsham, Providence in Early Modern England (Oxford University Press, 1999), 15.

8. See Helen Berry and Elizabeth Foyster, "Childless Men in Early Modern England," in The Family in Early Modern England, ed. Helen Berry and Elizabeth Foyster (Cambridge University Press, 2007), 158-83. 
has argued, "If even a normal childbirth was seen as a spiritually loaded event, the death of an infant might well be spiritually catastrophic." ${ }^{\text {F }}$ Furthermore, as Mack and other historians have demonstrated, the spiritual and cultural stigma for child loss often fell predominantly on the mother, who was typically instructed to "interpret the death as punishment of her own sinfulness." 10 Writing about the cultural meanings ascribed to pregnancy in seventeenth-century England, Laura Gowing notes that "Protestant stress on the significance of women's role as mothers, and popular medical books' focus on the best way of conceiving, intensified the weight contemporaries placed on women's childbearing capacity."11 For English Protestant mothers such as Carey, then, child loss would be interpreted within a complex set of personal, spiritual, and economic frameworks that had significant consequences for the patrilineal family.

As a result, it is not surprising that texts from this period frequently reflect on the palpable uncertainties at the core of England's patrilineal economy. The rigidity of the primogenitural model in legal theory did not result, of course, in a uniformity of practice, but it did mean that variations within this system were especially significant and often, especially for Protestant mothers, worthy of concern. Carey's writings offer a particularly rich case study for considering the available narrative and poetic resources for representing deviations or crises of lineage. What rhetorical tools can writers like Carey draw on both to make sense of these disruptions and to write them anew? To answer this question, I consider first the many genres and formal structures that Carey deploys throughout her manuscript, ranging from the mothers' legacy to the Protestant conversion narrative. Analyzing the formal components of Carey's writings reveals her use of a recurring, providentialist rhetorical strategy: the production of a counternarrative that negotiates between spiritual and earthly time. These counternarratives juxtapose two temporal structures, one human and one divine, and in doing so interrogate seventeenth-century genealogical discourses that put such intense pressure on childbearing. In this contrapuntal manner, they restructure the material relationships implied by primogeniture without overturning them completely. Providentialism enables Carey to fashion a poetic alternative to the tragedy of child loss, subtly revising the language of patrilineality.

Carey's prose meditation organized as "A Dialogue Betwixt the Soul and the Body" (dated 1649 in the manuscript) combines the structure of Pla-

9. Phyllis Mack, Visionary Women: Ecstatic Prophecy in Seventeenth-Century England (Berkeley: University of California Press, 1992), 37.

10. Ibid. See also Laura Gowing, Common Bodies: Women, Touch and Power in SeventeenthCentury England (New Haven, CT: Yale University Press, 2003), esp. 114-18.

11. Gowing, Common Bodies, 114. 
tonic dualism with a traditional Protestant conversion narrative that traces the progression from a life characterized by "Carding, Dice, Dancing, Masquing, Dressing, vaine Company, going to Playes, following Fashions, $\& y^{\mathrm{e}}$ like" (14r) to one of pious obedience to God's will. In blending these discourses, Carey participates in several long-standing literary traditions. The debate between the soul and the body was a popular medieval genre, revived in the early seventeenth century by writers such as Du Bartas and, perhaps most famously, Andrew Marvell in "A Dialogue Between the Soul and Body." 12 These later manifestations of the genre do not share the focus on death and divine judgment notable in their medieval predecessors and turn attention instead to relationship between the soul and the body in the context of Protestant modes of introspection.

The conversion narrative was a more recent genre that also flourished in the seventeenth century. Carey's text deploys a narrative pattern typical of the Protestant conversion narratives published in the mid-seventeenth century, the most famous of which is John Bunyan's Grace Abounding to the Chief of Sinners (1666). ${ }^{13}$ Such accounts usually describe a period of sin and wildness in the early years of the narrator's life, followed by a period of selfdespair and, ultimately, repentance and forgiveness. As D. Bruce Hindmarsh argues in his discussion of the genre, "forgiveness of sins comes, thus, as a climax and a psychological release from guilt, and ideally introduces a life of service to God predicated on gratitude for undeserved mercy." ${ }^{14}$ Like the maternal elegies for which she is better known, Carey's "Dialogue" draws on a rich textual history that includes some of the most popular and widely recognized genres of her day.

However, the initial impulse and governing premise for the dialogue is neither metaphysical reflection nor an exposition of sin and repentance per se but, rather, the death of a child. In her dedicatory epistle addressed to her second husband, Carey explicitly states her precondition for writing:

12. On Marvell's poem and its many literary precedents and sources, see Rosalie Osmond, "Body and Soul Dialogues in the Seventeenth Century," English Literary Renaissance 4 (1974): 364-403; Kitty Scoular Datta, "New Light on Marvell's 'A Dialogue between the Soul and Body,"” Renaissance Quarterly 22 (1969): 242-55; and Ian C. Parker, "Marvell's 'A Dialogue Between the Soul and Body': Probable Sources and Implications," Notes and Queries 55 (2008): 291-99.

13. Other early examples of Protestant conversion narratives include Richard Kilby's A Burthen of a Loaden Conscience (Cambridge, 1608); Henry Walker's compilation, Spirituall Experiences of Sundry Beleevers (London, 1653); and John Roger's collection of thirty-eight testimonials, Ohel or Beth-shemesh: A Tabernacle for the Sun (London, 1653).

14. See D. Bruce Hindmarsh, The Evangelical Conversion Narrative: Spiritual Autobiography in Early Modern England (Oxford University Press, 2005), 52. On the development of the Protestant conversion narrative during this period in England, see also Owen C. Watkins, Puritan Experience: Studies in Spiritual Autobiography (London: Routledge \& Kegan Paul, 1972). 
"The occasion of my writing this following Dialogue was my apprehending I should die on my fourth Child" (2r). This authorial position is transposed onto the figure of the Body in the dialogue itself. In the first line of the dialogue, the Soul asks the Body: "My sister, why art thou so sore cast down? hath anything befallen thee but what is the lot of God's people whose Sufferings are here onely?" (7r). The Body replies: "Dear Sister, the Lord hath taken from me a Son, a beloved Son, an onely Son, an onely child, the last of three, and it must needs affect me; Can a woman forget her sucking Child? that she should not have Compassion on the Son of her Womb? ... besides I am now neare the time of my travell, \& am very weake, faint, sickly, fearfulle, pained, apprehending much sufferings before me, if not Death itself, the King of Terrours" $(7 \mathrm{r}-7 \mathrm{v})$. Similar to the child loss elegies that appear later in the manuscript, Carey's prose meditation acknowledges the death of a son as a moment of personal, physical, and spiritual crisis, with potentially profound implications for the mother. As Pamela Hammons has demonstrated, such sentiments were common in seventeenth-century maternal elegies, given a cultural context in which the "intellectual, spiritual, and moral shortcoming of mothers were believed capable of replication in their offspring's bodies and destinies." ${ }^{15}$ But this passage also enacts what will become a larger rhetorical pattern in the "Dialogue" and, indeed, throughout the manuscript: a providential narrative of substitution that redefines the spiritual significance of the dead child. In telling the Soul that she is "now neare the time of [her] travell," the Body suggests that her anxieties about the future "sufferings" of childbirth help to explain her current distress, but at the same time those anticipated sufferings and the new birth that will accompany them provide symbolic replacements for her maternal grief.

Indeed, by invoking the image of the birth room as a deathbed-the feared link between the "time of my travell" and "Death itself"-Carey implicitly draws on another notable and extremely popular literary tradition: the genre of the mother's legacy, in which the impending death of the author in childbirth often provides rhetorical justification for her writing. As their name suggests, such legacy books were written by women to their children and were usually designed to offer guidance in both spiritual and practical matters to be followed after the mother's death. Some of the most famous texts in this tradition, including Dorothy Leigh's The Mothers Blessing (1616) and Elizabeth Jocelin's The Mothers Legacie, To her unborne Childe (1624), were seventeenth-century best sellers, published in multiple editions throughout the century. Although the genre of the mother's legacy is often associated with the rhetorical self-effacement of the author, these multifaceted texts sanction limited forms of female self-expression by

15. Hammons, "Despised Creatures," 27. See also Mack, Visionary Women, 35-44. 
banking on the cultural currency of maternal authority. ${ }^{16}$ As a counter to the narrative of human sinfulness foregrounded in many child loss writings, the genre of the mother's legacy may have been particularly attractive to writers such as Carey. In the opening exchange of her dialogue, for example, the trope of the concerned, expectant mother "neare the time of [her] travell" momentarily replaces the figure of the grieving, elegiac mother. Neither position, of course, provides an untroubled image of maternal agency, but this subtle substitution nevertheless makes visible a possible alternative to the cultural narrative in which child loss is figured as the ultimate end of fertility and lineage.

In deploying tropes characteristic of the genre of the mother's legacy to frame a text about the death rather than the birth of a child, Carey uses a technique also discernable in the writings of Elizabeth Isham (bap. 1608, d. 1654), an educated gentlewoman and sister of Justinian Isham who composed an autobiographical Booke of Rememberance (ca. 1639) around the same time as Carey's writings. ${ }^{17}$ Isham's narrative, like Carey's, is not a mother's legacy by strict definition; Isham remained unmarried and childless throughout her life, and many passages in her Booke of Rememberance recount the failure of various marriage negotiations that her father sought on her behalf. ${ }^{18}$ Isham's narrative nevertheless displays many aspects of the legacy genre, including the justification that she gives for writing her autobiography in the first place. In the narrative's early pages, when Isham is describing her impetus for writing her life story, she includes an intriguing marginal annotation that indicates she did not "intend to have th[is] published" but instead wrote "in praise a than[k]fullnes to God. And for my

16. For introductions to the genre of the mother's legacy and for the theme of authorial self-effacement in these texts, see Elaine V. Beilin, Redeeming Eve: Women Writers of the English Renaissance (Princeton University Press, 1987), 266-85; Kristen Poole, “"The fittest closet for all goodness': Authorial Strategies of Jacobean Mothers' Manuals," Studies in English Literature, 1500-1900 35 (1995): 69-88; Betty S. Travitsky, "The New Mother of the English Renaissance: Her Writings on Motherhood," in The Lost Tradition: Mothers and Daughters in Literature, ed. Cathy N. Davidson and E. M. Broner (New York: Ungar, 1980), 33-43; Wendy Wall, "Isabella Whitney and the Female Legacy," ELH 58 (1991): 35-62; and Valerie Wayne, "Advice for Women from Mothers and Patriarchs," in Women and Literature in Britain, 1500-1700, ed. Helen Wilcox (Cambridge University Press, 1996), 56-79.

17. See Kate Aughterson, "Elizabeth Isham (bap. 1608, d. 1654)," in Oxford Dictionary of National Biography, http://www.oxforddnb.com/view/article/68093.

18. The manuscript of Isham's Booke of Rememberance is housed at Princeton University Library (Robert C. Taylor Collection MS RTC 01 no. 62). Quotations from the Booke of Rememberance will refer to this manuscript, transcribed by Alice Eardley, and will be given parenthetically in the text. Thoroughly indexed versions of Isham's Booke of Rememberance, together with her vade mecum (housed in the Northamptonshire Record Office), are online at http://web .warwick.ac.uk/english/perdita/Isham/. For the depiction of arranged marriages in Isham's Booke of Rememberance, see Isaac Stephens, "The Courtship and Singlehood of Elizabeth Isham, 1630-1634," Historical Journal 51 (2008): 1-25. 
owne benefit. Which if it may doe my Brother or his children any pleasure I think to leave it them. Whom I hope will charitable censure of me" (2r, n. 2). Isham, like Carey, thus opens her text with one of the standard rhetorical gestures of the mother's legacy: in this case, the stated desire to bequeath her text to her descendants, Isham's brother and his children. ${ }^{19}$ Many authors of mothers' legacy books were either literally on their deathbeds or wrote metaphorically from that position, offering their texts as substitutes for legal wills. As Wendy Wall has argued, "The specter of death and the gravity of maternity join to produce a powerful counterforce to the culture's exhortations to silence." ${ }^{20}$ The language of bequeathal puts Isham's narrative in this same context. Indeed, toward the end of the manuscript, Isham refers rather clearly to her narrative as a legacy. She writes, "I told my Sister it may be I will leave my mind to my friends when I die to give them satisfaction," a statement that serves as partial justification and rationale for her life writing and explicitly ties that writing to the concept of bequeathal or legacy (30r).

The generic tropes of the mother's legacy provide Isham with a template that restructures her personal narrative in socially recognizable terms. When her father, for instance, invites her brother, sister-in-law, and children to come live with them, Isham praises God for "my Brothers children which thou art now pleased to lend unto me” (33v). The language of lending, common to both child loss poetry and mothers' legacy books, grants Isham a temporary role as a maternal substitute or adjunct. As such, Isham's nieces and nephews rhetorically substitute for biological children in her narrative. The logic of maternal substitution becomes more explicit later in the text, after the death of Isham's sister-in-law. She comments in a marginal annotation that she would be "willing to obey" God's command to take care of her sister-in-law's children, should the need arise $(34 \mathrm{v}) .{ }^{21}$ Once again, Isham recuperates for herself a maternal role despite her own childlessness. Like Carey's “Dialogue," Isham's Booke of Rememberance offers an alternative model of the mother's legacy, one that disassociates it from the literal biography of its author. Mothers' legacy books, in other words, model a rhetorical persona more than an autobiographical stance, and that persona can be deployed in figurative ways by writers such as Carey and Isham to glean a limited degree of textual authority. By substituting the persona of the mater-

19. Isham's stated desire that her brother and his family will judge her charitably is also rhetorically similar to the language of female defense narratives, such as the autobiographical accounts of Anne Halkett and Alice Thornton.

20. Wendy Wall, The Imprint of Gender: Authorship and Publication in the English Renaissance (Ithaca, NY: Cornell University Press, 1993), 284.

21. Indeed, we know from Elizabeth Isham's other autobiographical manuscript, Northamptonshire Record Office IL3365, that she did, in fact, care for her nieces Jane and Susanna after her sister-in-law's death in 1639 and until around 1644. 
nal author for that of childless woman or grieving mother, these writers do not erase the images of barrenness that characterize their texts, but they do reposition those images within a textual frame that offers more promise of social recognition and an alternative narrative of maternal agency.

Returning to Carey's "Dialogue," we see that this rhetoric of substitution is characteristic of the text as a whole, though it often functions in more figurative terms. In response to the Body's initial complaint that "the Lord hath taken from me a Son," for example, the Soul offers an explanation in which a providential understanding of time substitutes for an earthly one. The Soul tells the Body: "First, For the removall of the Child, know, that it is Gods Will, to which submit, not one word; and do not onely yield, but approve; God is wise, and knowes it best; God is loving, and therefore did it" $(7 \mathrm{v})$. In the Soul's formulation, God operates according to a different plot and a different temporal logic than do humans. The rationale for the child's death is God's omniscient wisdom, but such wisdom is grounded in a conception of time that privileges the long view over the temporary and local, the grand sweep of Christian human history over the individual moment of personal or familial suffering. This spiritual time frame is a hallmark of the doctrine of providence for English Calvinists. As Alexandra Walsham describes it, providence was "the single teleological thread which wove together past, present, and future, the blueprint for human history drawn up in the beginning." 22 But for Carey, the doctrine of providence also has narratological implications; the privileging of a spiritual time frame implies certain rhetorical and structural choices. In "Forms of Time and of the Chronotope in the Novel," Mikhail Bakhtin demonstrates that different ways of reckoning time have direct implications for narrative form. For example, describing the "struggle between living historical time and the extratemporal other-worldly ideal" that occurs in medieval dream vision, Bakhtin notes that the form of the spiritual narrative wins out over the local, historical moments it incorporates, in the process rejecting "the inability to see the whole of time that is implicit in any historical interpretation." ${ }^{23}$ A similar rhetorical structure is at work in Carey's "Dialogue." In Carey's text, the child has not been completely lost but has been removed to a different setting, beyond both the physical world and the scope of rational perception. Furthermore, questioning this action is futile because God's wisdom encompasses a nuanced understanding of causality - a more flexible and expansive time line-that is beyond the grasp of ordinary humans. Thus, the Body must "not onely yield, but approve." The Soul's response offers a

22. Walsham, Providence in Early Modern England, 9.

23. Mikhail Bakhtin, "Forms of Time and of the Chronotope in the Novel: Notes toward a Historical Poetics," in The Dialogic Imagination: Four Essays, ed. Michael Holquist, trans. Caryl Emerson and Michael Holquist (Austin: University of Texas Press, 1981), 158. 
counternarrative to the Body's physical suffering, one that deflects presenttense material concerns by shifting focus to a narrative that operates according to a spiritual rather than an earthly model of time.

Carey makes use of similar rhetorical formulations throughout her prose dialogue, which features a conversion narrative voiced by the Soul and celebrated by the Body as a reassuring sign of God's love and providence. In recounting her story of conversion, the Soul emphasizes the solace that she finds in prayer, even when she approaches God with a sinful and troubled heart. She tells the Body: "I know, that when I have gone to God in a negligent, formall, carelesse, selfish manner, then I got nothing but shame of Face, \& griefe of Heart. And many, yea, innumerable times have been $\mathrm{y}^{\mathrm{e}}$ Indisposition \& evill Disposition of my heart to, \& in Prayer. My Memory is charged, and overcharged $w^{\text {th }}$ Miscarriages in this kind, but when ever I have carried my heart to God, I have found immediate Mercy" $(76 \mathrm{v}-77 \mathrm{r})$. The fascinating use of the word "miscarriages" in this context signals a generic shift in Carey's narrative. Meaning "an instance of misconduct or misbehavior" and "the spontaneous expulsion of a fetus from the womb before it is viable," 24 the word "miscarriages" both reinstates the initial premise of the "Dialogue" — the death of a child-and shifts the text toward a conversion narrative in which it is one's approach to prayer and repentance rather than one's body that can miscarry. As such, the conversion narrative, like the mother's legacy, provides a formal substitute for the dead child and miscarrying mother. Subsumed into a story of spiritual redemption, the parental sinfulness implied by the death of a child can be repositioned as the origin of a narrative of repentance and mercy rather than as the end point of a narrative of grief or barrenness.

However, though Carey attempts to replace the narrative of child loss with a spiritual narrative of redemption, this substitution is never a total one, nor is it meant to be. Because Calvinists understood that God's providence worked in both "general" and "special" forms (the former describing God's overarching plan for the world and the latter usually denoting God's more particular interventions in human life), belief in divine providence entailed not just a simple substitution of a divine plan for human experience but, rather, a careful scrutiny of earthly events in order to assess one's state of salvation. ${ }^{25}$ Carey's "Dialogue" demonstrates this contrapuntal logic, retaining throughout a subtle negotiation between the Soul and the Body and between the kinds of maternal language that each espouses. In the midst of her story of personal conversion, for instance, the Soul reinstates the physical loss that God's mercy is supposed to have deflected. She tells the Body that she has "never carried a troubled heart unto $\mathrm{y}^{\mathrm{e}}$ Lord in

24. Oxford English Dictionary Online, http:/ /www.oed.com, s.v. "miscarriage," defs. 1, 4a. 25. See Walsham, Providence in Early Modern England, esp. 8-20. 
prayer" but then quickly adds parenthetically, "\& I thinke I have had as often, \& as greatly a distressed heart in several extremities as many have had" (78v). The speaker's sufferings may be syntactically demoted, but they are nevertheless present, even here in the last twenty folios of the "Dialogue." Indeed, this final portion of the Soul's narrative includes a rousing expression of gratitude for God's mercy that is palpably marked by the physical remembrance of loss. The Soul recounts: "When I have foreseen, \& apprehended any great Suffering before me, as the death of my children, (a heart terrifying Sorrow,) or some hideous Temptation, or Death ... God ... hath been $w^{\text {th }}$ me in all times, $\&$ in all straights, \& hath ever given me free, full, sudden, certaine, hearing, answering Mercies in Prayer" $(79 \mathrm{v}-80 \mathrm{r})$. In the margin next to "as the death of my children" appears the additional phrase " $\&$ all my Children were only children, each child when it died was all that I had alive" $(79 \mathrm{v})$. In this remarkable passage, the speaker's dead children provide the suffering and impetus for prayer, yet they are also metaphorically supplanted by the "answering Mercies" she receives from that prayer. Physical miscarriage has again been converted into spiritual benefit, but to do so the "heart terrifying Sorrow" conditioned by the original loss must not be erased but repositioned (in this case parenthetically) as the linchpin or key to reconciling the daily with the divine.

The blurring between the Soul and the Body further reveals the productive synergy between the local and the spiritual in Carey's "Dialogue." The entire conversion narrative itself, including the revelations about her youthful sickness, supposed debauched behavior, and the later death of her children, is told by the Soul, not the Body. Though the dialogue does privilege the Soul as a source of wisdom, the body and its physical concerns (including child loss, the opening premise of the dialogue) are always palpably present. Indeed, the Soul often speaks a language of physicality ("my flesh hath crept for feare" $[79 \mathrm{v}]$ ) that seems entirely more suited to the Body, while the Body frequently gives scriptural warrant for its grief. ${ }^{26}$ Such a mixing of figurative registers is to a certain extent typical of the soul/body dialogues to which Carey is indebted. In Marvell's "Dialogue," for example, the Soul lambasts the Body for enslaving him "with bolts of Bones" and "Chains / Of Nerves, and Arteries, and Veins," but the Body similarly rails against the "bonds of this Tyrannic Soul," which "stretcht upright, impales me so." 27 However, unlike Marvell's consistently antagonistic Soul and Body, Carey's Soul and Body pursue an entirely congenial exchange. The blurring of their subject positions in the "Dialogue" is not part of a metaphoric competition to determine whether the Soul or the Body is superior,

26. See, e.g., $7 \mathrm{r}-7 \mathrm{v}$.

27. Andrew Marvell, "A Dialogue between the Soul and Body," lines 3, 7-8, 12, and 13, in The Poems of Andrew Marvell, ed. Nigel Smith, rev. ed. (Harlow: Pearson Longman, 2007), 61-64. 
as is the case in Marvell's poem and in many other texts in the tradition. Rather, the interchange between these two figures takes the form of instruction and substitution- the Soul instructs the Body and offers sage advice in place of grief-while simultaneously suggesting a more fluid relationship in which the body, and physical language more generally, are never fully erased.

The Soul's assertion that "all my children were only children"-positioned in the margins, in a dialogic relationship with the main text—also implies a negotiation in the "Dialogue" between two different ways of reckoning time. This contrasting temporality is even more noticeable in a prose meditation found later in the manuscript, "A Commemoration of the Love of God the Father, Son and Holy Ghost." ${ }^{28}$ Reflecting on God's mercies, the speaker of the meditation notes: "Many great Sufferings I never tasted, as Want of any outward necessary Mercy I never knew; I never wanted House, nor Land, loving Friends, usefull Servants, Food, Raiment, $\mathrm{y}^{\mathrm{e}}$ Comfort of Parents, or in their absence of Children, or in their absence of my Husband" $(100 \mathrm{v})$. In celebrating the divine mercies she has received, Carey's speaker offers another series of substitutions that seems to work against the stated premise of the speaker's praise, namely, that she has "never tasted" many great sufferings. In substituting children for parents and husband for children, the passage syntactically rewrites the loss of both parents and children so that they become signs of God's "outward necessary Mercy." But as a form of apophasis, the passage also records absence as well as presence, passing over loss and suffering on the way to mercy yet also making visible that very process. The spiritual narrative that governs the prose meditation (and that constitutes the "plot" of Protestant conversion narratives) produces a chronology of salvation and divine grace that is nevertheless built upon a series of discrete moments of loss or absence that can be reinscribed within a larger narrative. On the one hand, this formulation privileges the providential long view, an omniscient temporal perspective that provides an overarching structure in which to locate and make sense of local tragedies. On the other hand, like the Soul's insistence in the "Dialogue" on the status of all her children as "only children"-a statement that is only true if considered from a specific, past moment in time rather than in retrospect-Carey's meditation constructs that providential understanding of time out of the more local moments it ultimately seeks to rewrite.

A similar moment occurs earlier in the manuscript, in Carey's epistle to her husband. Again pairing the loss of children with a resignation to God's will in conventional fashion, Carey reminds her husband: "God hath given us diverse sweet babes, and though he hath in Wisedome remov'd them from our present Sight, yet are they in the Bosome of God, and we shall

28. This meditation appears on fols. $96 \mathrm{v}-104 \mathrm{v}$ in the Bodleian MS. 
find them one Day made perfect in Glory" (5v). The idea that the children have been removed from their parents' "present Sight" is richly suggestive, implying an understanding of vision that is disassociated from the typical human experience of time. The concept of "present sight" presumes the existence of a "future sight" that functions according to the temporality of divine providence rather than earthly experience. The fact that Carey in her epistle immediately goes on to express her gratitude to God for specific historical events (e.g., that she and her husband have been "kept together" despite the "separating Troubles" of the Civil Wars [5v]) further situates the "diverse sweet babes" within a different historical time line, one that assumes a large instead of a local view of human experience and lineage. Still, the rapid shift between these two temporal registers and the indelible image of the "diverse sweet babes" that resonates in this passage (again, a form of apophasis) retain the memorial presence of loss and suffering while reformulating such memories for new, spiritually efficacious uses.

This counterpoint between spiritual and earthly temporalities-a structure that in many ways derives from the genres of the soul/body debate, the mothers' legacy, the conversion narrative, and the spiritual meditation that Carey uses in her manuscript-makes it possible for a new narrative about maternity and lineage to emerge. The Soul's narrative affirms that "God hath fitted me for a Cross, \& made that easy when it came, $w^{\text {ch }}$ afar off seemed insupportable" (80r). The Body's general response to this narrative, repeated in various forms throughout the "Dialogue," is particularly resonant: "Ah! Deare Soule," says the Body, "what a large story hast thou told me of Mercies" (24r). ${ }^{29}$ In this context, the word "large" not only refers to the overall length of the story itself but also suggests God's munificence, a capacity for generosity that is specifically bound up with the capaciousness of the Soul's narrative. As such, the rhetorical dilation of the story produces a new context for reading the physical tribulations associated with generational increase in Carey's writing. ${ }^{30}$ The Soul's "large story" provides a metanarrative that both incorporates and rewrites the present-tense struggles and daily stories of the body-the individual moments of temptation, sin, and doubt. This broader, providential narrative offers a reassuring substitution for the physical pains of the Body while also making visible the fact that such divine reassurance is ultimately necessitated by sin and suffering. Physical trauma becomes the starting point in a new story about God's grace rather than the ending point in a story about maternal

29. The Body's response near the end of the "Dialogue," for instance, similarly emphasizes the expansiveness of both God's grace and the Soul's narrative: "Ah! my deare Soule! ... the Mercy he hath shewed thee is of an endless Nature, shall last for ever, \& ever" (89v).

30. On rhetorical dilation and its connection to physical generation, see Patricia Parker, Literary Fat Ladies: Rhetoric, Gender, Property (London: Methuen, 1987), 8-35. 
loss, but trauma nonetheless remains a prominent feature of the story. It is precisely by repeating and scrutinizing such tragic events that Carey's speaker is able to exert a rhetorical and spiritual control over the process of loss, thereby creating a space for maternal authority to emerge.

Throughout the Soul's advice to the Body, memories of material loss get similarly rewritten through images of divine mercy. The Soul tells the Body to "let y $\mathrm{e}^{\mathrm{e}}$ Consideration of God's free, full, singular, continuall, constant, eternall, best Love to me, stir up, \& encrease abundantly my Love to him" (92v-93r). Like the earlier reference to "miscarriages," the imagery of abundant "increase" metaphorically translates the concept of physical reproduction and fertility to one of spiritual effusion without eroding the material connotations that produced the original image. The Soul's narrative amplifies and expands on the Body's experiences, transforming a limited, linear story of physical reproduction into a larger, spiritual genealogy. As a result, the dialogue between the Soul and the Body does not produce two discrete narratives about human sinfulness or divine grace. Instead, two narratives are intricately bound together. By emphasizing forgiveness and God's mercy, the Soul reminds us that humanity's sinful condition, in providential theology, is ultimately to blame for the miscarriages. At the same time, the "Dialogue" insists that miscarriage need not be the end of the family line or the end of the story, if understood in spiritual terms. What emerges from Carey's text is a complex counterpoint between Soul and Body that yields a new narrative of lineage, one in which miscarriages and the loss of lineage that they represent are repositioned within a spiritual time frame, a "large story" that ultimately recuperates maternal agency.

Writing about the friendship poetry of Katherine Philips, Valerie Traub has argued that Philips creates a "poetic stance which ... conflates rather than separates the spiritual and the bodily." While some of Philips's poems assume a binary opposition between these two categories, others "rhetorically merge these affective registers" with the aim "not to elevate the spiritual in a transcendence of the body, but to reject the opposition." Traub goes on to suggest that these poems, which are "often elegiac," attempt to "overcome the absence and loss of the beloved's presence through a determined negation of difference and distance." 31 This analysis of Philips's elegiac lyrics helps illuminate one of the dominant impulses in Carey's writing; namely, her resistance to the dichotomies that typically characterize the soul/body divide. Like Philips, Carey often merges spiritual and earthly sensibilities, performing a "determined negation of difference and distance" that works within and against the elegiac tradition of maternal lament. Similarly, the intermixing of spiritual and earthly temporalities in

31. Valerie Traub, The Renaissance of Lesbianism in Early Modern England (Cambridge University Press, 2002), 302. 
Carey's prose transforms an oppositional structure into a contrapuntal one. While the providential view of time and human suffering seems to imply a broader perception and an awareness of chronology, Carey also retains an emphasis on local history and the personal experience of solid, present moments. Indeed, I would suggest that for English Calvinists, the broader, spiritual concept of time posited by providentialism actually enables a reconceptualization of the experience of earthly time. It is only through accepting the reassuring long view of time and divine mercy that Carey's speaker can develop a rhetorical and mental space in which to articulate the individual sufferings, memories, and experiences that a providential time line ultimately seeks to occlude. Like the structure of a musical fugue, in which the main theme does not change but the counterpoint between voices enriches and shifts the contours of that theme through repetition and modulation, the persistence of the soul/body divide throughout Carey's writings serves not to harden these categories but, rather, to rework them subtly into new variations.

One of the things that such a contrapuntal structure does is create a multivocal, even multidimensional alternative to the vertical model of patrilineality that obtained in mid-seventeenth-century England. Canonical, male-authored elegies of the period tend to focus on lines of succession and the "construction of heroic genealogies." 32 Authors such as Carey, however, renegotiate the terms of succession by creating a new narrative of genealogy that operates in the space between spiritual and earthly temporal logics. This narrative reconstructs maternal lineage and family history out of what initially might appear to be unfruitful material: iterations of specific griefs and losses that configure lineage in local terms, rooted in memory. ${ }^{33}$ We can trace this rhetorical and spiritual process throughout Carey's prose meditation, even near the end of her "Commemoration," when she acknowledges a change in her fortune, noting that though one child "was my greatest number formerly," now God "gives, \& continues me" two healthy children, a son and a daughter named Nathaniel and Bethia (103r). The spiritual logic of substitution provides two children in place of one, a formula that seems to offer clear evidence of divine mercy and providence. However, rather than ending her story here on an unequivocally forward-looking note, Carey's speaker instead continues by asking God:

32. Kate Lilley, “True State Within: Women's Elegy, 1640-1700," in Women, Writing, History, 1640-1740, ed. Isobel Grundy and Susan Wiseman (Athens: University of Georgia Press, 1992), 73.

33. In a similar vein, Megan Matchinske explores the ways in which Anne Clifford produces a "new kind of personal history" through the formal, temporal structure of her diary writings. See "Serial Identity: History, Gender, and Form in the Diary Writing of Lady Anne Clifford," in Dowd and Eckerle, Genre and Women's Life Writing, 65-80, esp. 66. 
"let their Births, \& all $y^{\mathrm{e}}$ rest never be forgotten by me; \& all my Deliverances of each of them all" (103v). The intrusion of "all" into the celebration of a specific two subtly reframes the spiritual mathematics of the passage, insisting that healthy children do not simply replace but rather follow from (and in many ways depend on) those who have died, just as current conditions incorporate rather than displace painful memories. Carey's speaker happily accepts divinely given substitutes for her losses, but she also insists on keeping memories of those original sorrows present and viable. Similarly, Carey's providential rhetoric throughout her prose meditations is neither clearly liberatory nor oppositional. Rather, it produces a negotiation between general and special forms of providence and between earthly and spiritual ways of reckoning lineage that opens up alternatives to commonplace seventeenth-century discourses that associated barrenness and child loss with social or spiritual insufficiency.

If we turn now to reading Carey's poetry within the rhetorical context of her prose meditations, we can see how the child loss poems deploy similar counternarratives. The rhetoric of providential substitution that is developed throughout the prose is prominent in the lyrics. In a short poem lamenting the death of her " 4 th, \& only Child, Robert Payler," Carey writes:

\author{
My lord hath called for my sonne \\ my hart breth's forth; thy will be done: \\ my all; that mercy hath made mine \\ frely's surendered to be thine: \\ But if I give my all to the \\ lett me not pyne for poverty: \\ Change $\mathrm{w}^{\text {th }}$ me; doe, as I have done \\ Give me thy all; Even thy deare sonne.
}

$$
(1-8)^{34}
$$

As Hammons argues, in this poem Carey deploys a conventional "consolatory strategy" of maternal elegies, the transformation of loss into exchange as the bereaved parents receive Christ in place of the dead child. ${ }^{35}$ Read in the context of the prose meditations, however, we can also see a contrapuntal exchange between spiritual and earthly registers at work here. Despite

34. Mary Carey, "Written by me at the same tyme; on the death of my 4th, \& only Child, Robert Payler," in Kissing the Rod: An Anthology of Seventeenth-Century Women's Verse, ed. Germaine Greer, Susan Hastings, Jeslyn Medoff, and Melinda Sansone (New York: Noonday, 1988), 156-57. Quotations from Carey's lyrics refer to line numbers and are taken from the Greer et al. edition, which reprints the poems directly from the autograph manuscript. The poem appears on fol. 95v in the Bodleian MS.

35. Hammons, "Despised Creatures," 30. 
the speaker's forthright statement of acquiescence in the first couplet, the exchange with God is ultimately predicated upon the speaker's conditional "if" in line 5. And, as Lisa Schnell has noted, Carey's speaker "insists on her right to continued maternal property," even though that right conflicts with a full surrender to God's will. ${ }^{36}$ The long temporal view supplied by providentialism, in which Christ is a more than suitable exchange for the dead child, once again exists simultaneously with the more local view of maternal history, which emphasizes personal poverty and a specific moment in timethe moment when Robert Payler was the speaker's only child.

A similar logic of exchange characterizes another of Carey's short lyrics commemorating the death of her fifth child, Perigrene Payler. Once again, Carey's speaker finds consolation in the reciprocal relationship she shares with God. Although she must send Perigrene "back againe" (4), she nevertheless claims that her only blessing is that "he is mine; and I am his" (8), referring to her "Lord Christ" (7). ${ }^{37}$ In the final couplet of the poem, the speaker addresses God directly: "My Dearest Lord; hast thou fulfill'd thy will, / thy hand maid's pleas'd, Completely happy still" (9-10). The insistent, even triumphal, present tense of these lines emphasizes the conjunction of God's providential plan and the speaker's current, earthly experiences. However tragic the loss of this child is in temporal human terms, the speaker's insistence that she is nevertheless "Completely happy" relocates such tragedy within a providential time frame, a process that both acknowledges and elides the elegiac. In essence, these lines make clear that all tragedy is local if considered within a providential narrative; Carey enacts that understanding here by investing earthly barrenness with spiritual fertility. ${ }^{38}$

The final poem in the manuscript, "Upon ye Sight of my abortive Birth," is by far the longest of Carey's lyrics and has received more critical attention than any of her other writing. Like the shorter poems, this elegy takes on new meaning when read in terms of the contrapuntal narratives at work in the prose meditations. The poem's opening lines, which apostrophize the dead child, insist on locating this death within a specific narrative of family history:

What birth is this; a poore despissed creature?

A little Embrio; voyd of life, and feature:

36. Schnell, "Lett me not pyne for poverty," 16.

37. Mary Carey, "Wretten by me at the death of my 4th sonne and 5th Child Perigrene Payler," in Greer et al., Kissing the Rod, 157-58. The poem appears on fol. 96r in the Bodleian MS.

38. Carey returns to the phrase "Compleatly happy still" in her later poem "Upon ye Sight" (32), reiterating both her submission to God's will and her conflation of earthly and spiritual temporal registers to construct happiness out of tragedy. See "Upon ye Sight of my abortive Birth ye 31th: of December 1657," in Greer et al., Kissing the Rod, 158-61. The poem appears on fols. $114 \mathrm{r}-117 \mathrm{v}$ in the Bodleian MS. 
Seven tymes I went my tyme; when mercy giving deliverance unto me; \& mine all living:

Stronge, right-proportioned, lovely Girles, \& boyes 5 There father; Mother's present hope't for Joyes:

That was great wisedome, goodnesse, power love praise to my deare lord; lovely in all his wayes:

This is no lesse; ye same God hath it donne; submits my hart, that's better than a sonne:

In giveing; taking; stroking; striking still; his Glorie \& my good; is. his. my will:

In that then; this now; both good God most mild, his will's more deare to me; then any Child.

The speaker locates the dead child within a family genealogy that both suggests the passage of years ("Seven tymes I went my tyme") and insists on the spiritual equivalency of the successive births-regardless of their outcomes ("This is no lesse"). Likewise, though the narrator clearly defers to God's will, "more deare" than "any Child," the parallel structure and the odd juxtaposition of possessive pronouns in the poem's twelfth line imply an equivalency between God's will ("his") and the speaker's ("my"). The phrase "is. his. my will" thus translates the speaker's obedience to God into a grammatical structure that continues to assert the importance of "my"- the speaker's own agency. ${ }^{39}$ This syntax of submission paradoxically grants the speaker a divinely sanctioned authority that validates her role in mothering a "poore despissed creature" alongside her nurturing of "right-proportioned, lovely Girles, \& boyes"; both activities are worthy of "great wisedome, goodnesse, power love praise." As in the short poem on the death of Robert Payler, the opening lines of "Upon ye Sight" vividly display both the redemptive substitution of grace for sin and the more local moments of loss implied by the phrase "This is no lesse."

The spiritual correspondence in the poem between still and live births works in part to mitigate the social stigma placed on barrenness and miscarriage in the period. By insisting that she has been "made Instrumentall" to God's will, Carey's speaker deflects concerns about her own state of grace. But the poem goes further: it situates the miscarriage within a larger,

39. Hammons similarly argues that this line "questions the relationship between God as subject and herself [Carey] as subject" ("Despised Creatures," 42). 
divinely sanctioned temporal scheme. In the margins of her poem, Carey includes biblical citations that serve to gloss individual lines and passages. Sometimes she simply paraphrases or even repeats word for word the language of the Geneva Bible. ${ }^{40}$ Other glosses are more thematically and symbolically resonant. The speaker of Psalm 119, for example, which Carey's poem refers to on six separate occasions, asks God to "quicken me in thy way" (39) and to "quicken me according to thy loving kindenes" (159). ${ }^{41}$ Like the word "miscarriages" in the "Dialogue," the "quikning grace" desired by Carey's speaker attests both to the instrumentality of God's will and to her own desire to produce another child (80). ${ }^{42}$ The metaphoric conflation of spiritual grace and physical conception in the concept of "quickening" subtends both the psalm and Carey's elegy; the speaker longs to be filled with God's grace, but the quickening she seeks also implicates her in the creation of new life, a new lineage.

The reference to "quikning grace" in Carey's poem produces a counternarrative of maternal authority that both is and is not dependent on the speaker's total submission to God's will and a providential temporal scheme. Though the concept of spiritual quickening offers a reassuring replacement for barrenness, the physical implications of quickening also reestablish successful, embodied maternity in its own right. In this case, Carey's speaker looks forward and does so in order to imagine physical, earthly happiness as well as divine mercy. The double meaning embedded in the word "quickening" thus presents a rhetorical opportunity to Carey, as it does to Isham in her Booke of Rememberance, a text to which I wish briefly to return. Isham's autobiographical narrative deploys the image of quickening in a strikingly similar manner to Carey's "Upon ye Sight." In the later portions of her narrative, Isham makes several references to Psalm 119 and the concept of "quickening." Writing as a childless woman asking for God's blessing, Isham makes use of the contrast between barrenness and God's quickening grace to establish an alternative model of legacy. For Carey, the poetic appeal to God rhetorically counteracts her own experience of child loss; Isham's call for spiritual quickening functions similarly to offset her own childlessness. For both writers, it is the contrapuntal relationship between spiritual and earthly formulations of time that enables these alternative, future-looking narratives of maternal sufficiency to emerge.

40. On Carey's use of the Geneva Bible, see George Parfitt, English Poetry of the Seventeenth Century (New York: Longman, 1992), 230.

41. Carey refers to Psalm 119 at lines 29, 52, 81, 82, 83, and 85.

42. See the headnote to Psalm 119 in the Geneva Bible, which reads, "The Prophet exorteth the children of God to frame their lives according to his holie worde. ... Also he sheweth wherein the true service of God standeth ... when we serve him according to his worde, \& not after our one fantasies." On Carey's biblical citation as an "act of authorization," see Schnell, "Lett me not pyne for poverty," 18. 
Like Carey, Isham also blames herself for the death of a child-though, in her case, for the death of her nephew. Indeed, Isham's language at the death of her nephew often mirrors the conventional expressions of maternal guilt that are common to child loss poetry of the period. She writes: "when the Child fell ill my mind checked me because I thought my self unworthy of that part which I had in him, being not thankfull to thee enough for him, for I somtimes douted of his life tho I saw no cause in the child but he might have lived: and thou which madest him so strong and perfect to our wonder couldest as well have preserved him. But pardon my unthankfullness and weaknes of faith" (34v). Here, Isham reflects momentarily on her own frustration at God for the child's death, suggesting that God could have preserved the child even as he made him "strong and perfect to our wonder." But she concludes the passage by firmly reasserting that her own "unthankfullness and weakness of faith" contributed to the child's early demise. Co-opting the language of maternal loss, Isham transforms the life of a single, childless woman into a narrative of maternal stewardship that ultimately aligns her with God's will. ${ }^{43}$ This is, to be sure, an ambivalent strategy at best, since it relies on images of loss to establish a position of parental authority. But in subtly laying claim to the language of maternity, Isham rewrites the terms and significance of her own childlessness, repositioning herself within the "large story" of sin and divine forgiveness that I have been tracing in Carey's writings. Childlessness in Isham's text, as in Carey's, is thus figuratively rewritten so as to be compatible with rather than antithetical to maternity, legacy, and spiritual grace.

Similarly, many of Carey's marginal glosses articulate a spiritual time line that offers an alternative to her maternal losses. Carey's eighteenth couplet asks God to provide a reason for her miscarriage, to explain what she has done to deserve God's punishment. The speaker asks: "What he doth spy; what is the thinge amisse / I faine would learne; whilst I ye rod do kisse." The marginal note refers to Micah 6:9, which reads: "The Lords voyce cryeth unto the citie, and the man of wisdome shal se thy name: Heare the rod, and who hathe appointed it." The speaker in Carey's poem thus positions herself as the "man of wisdome" who hears the rod and God's authority, but she also acknowledges the link between her body and the "sinful citie" of Micah. While retaining an emphasis on human sinfulness, this reference also suggests the potential to grow from a corrupt foundation-a theme developed extensively in Micah through images such as the planting of the vineyard in chapter 1. Indeed, Carey's elegy returns to the image of the vineyard when the speaker addresses God in the colloquy

43. Isham invokes the concept of stewardship early in her Booke of Rememberance: "wee are the Lords steurdes and must give acount how wee dispose of that wee have" (11v). 
section of the poem: "But lord since I'm a Child by mercy free; / Lett me by filiall frutes much honnor thee; / I'm a branch of the vine; purge me therefore; / father, more frute to bring, then heertofore" (68-71). ${ }^{44}$ These lines are glossed by John 15:8 and John 15:2, taken from the parable of the vine. Through its biological and figurative references to reproduction, this biblical gloss reimagines the maternal role of the poem's speaker. On the one hand, this image recuperates maternal authority paradoxically by substituting God's agency for the speaker's own: ultimately it is God, not the speaker or individual mother, who is responsible for birth. ${ }^{45}$ But the biblical reference also produces an effective counterpoint to this maternal elegy, suggesting that when reproduction and lineage are understood in spiritual instead of earthly terms - in terms of a much broader, providential understanding of chronology-it no longer becomes difficult to construct fertility out of barrenness, a "large story" out of more local human sufferings.

The poem's marginal glosses also position its speaker as a preacher and conveyer of God's word, an idea that amplifies the concept of "quikning grace" in the poem. Midway through the elegy, Carey creates an embedded dialogue in which God chastises the speaker for presenting him with "dead frute," "dead dutys; prayers; praises" $(40,42)$. Carey here cites Revelations 3:1, which the Geneva Bible glosses as follows: "The minister liveth when he bringeth forthe good frutes, els he is dead." As the word "frutes" is Calvinist shorthand for the fruits of the spirit (see Gal. 5:22), this image again conflates physical and spiritual understandings of childbirth, positioning the speaker as a minister of God's word, albeit one who has in this case brought forth "death frute." However, in the colloquy section of the poem, Carey's speaker asks God that her heart "tarie; / Till it be form'd; of Gosple shape \& sute," marginally glossed by Philippians 1:27, in which Paul tells the Philippians to "let your conversation be, as it becometh the Gospel of Christ, that whether I come and se you, or els be absent, I may heare of your matters that ye continue in one Spirit, \& in one minde fighting together through the faith of the Gospel." The end of the poem thus revisits the dialogic structure of the earlier prose meditation to reinstate Carey's speaker as one able to "converse" about spiritual matters, a verbal reproducer, as it were, of "Gosple shape." This gloss sets up an alternative arena for the speaker's maternal labors; the narrator both begs for another chance at motherhood and establishes a series of spiritual equivalences (the branch reproduces the vine, the minister reproduces God's word, her own poem reproduces her spiritual meditation) that offset the miscarriage.

44. For the formal structure of the poem (composition, analysis, colloquy), see Anselment, "A heart terrifying Sorrow," 21. For the poem's meditative aspects, see Long, "It is a lovely bonne I make to thee," 262.

45. See Hammons, "Despised Creatures," 44-46. 
As in her prose meditations, Carey's contrapuntal rhetoric in "Upon ye Sight of my abortive Birth” relocates the speaker's personal tragedy within a divinely sanctioned temporal order. Despite its ostensible focus on personal family history and suffering, the poem nevertheless establishes a spiritual time line that places the narrator's reproductive activities within the context of God's providence and "quikning grace." The elegy thus compensates for seventeenth-century cultural concerns about barrenness and miscarriage by shifting focus to the spiritual alternatives to reproductive labor that are available to the woman who is "made Instrumentall" by God. "Upon ye Sight of my abortive Birth" effectively reinstates the speaker's lineage and the existence of her descendants over time-the very things that miscarriage threatens to eradicate. In doing so, it also gives a form and a history to the formless birth ("voyd of life, and feature") that has instigated the narrator's grief and meditation.

However-and here is where situating Carey's lyric alongside her prose proves particularly instructive-the compensation provided by this spiritual genealogy does not simply replace the speaker's physical, earthly experiences. Rather, Carey's providential rhetoric enables her to imagine a meeting ground between personal tragedy and divine omniscience. In "Upon ye Sight," the contrapuntal relationship between divine and earthly temporalities developed in the prose meditations becomes visible in the relationship between text and margin. Carey's poem invites a process of reading and interpretation that requires comparison, cross-referencing, and synthesis; the biblical marginalia produce a dialogic structure that brings into being an alternative understanding of maternal lineage.

Carey's prose meditations and elegies make visible an alternative to the strictly linear model of patrilineal inheritance that theoretically held sway in early modern England. By substituting a more expansive, spiritual time frame for the limited, human chronology of barrenness and loss, these texts imply that lineage is, in fact, more flexible and more multidimensional than England's patrilineal economy might suggest. Indeed, despite the fact that seventeenth-century ideologies about childbirth and lineage often directed particularly intense scrutiny on mothers, Carey pointedly does not deploy a language of maternal failure per se but instead turns to the spiritual and rhetorical possibilities afforded by providential doctrine to reframe genealogical meaning. The concurrent, contrapuntal genealogies that characterize both Carey's prose and poetry negotiate between the body and the soul, human suffering and divine mercy, child loss and God's eternal providence, and as such they open up a discursive space in which maternal agency can be at least temporarily recuperated. Given the constraints of her chosen genres, this space is a fleeting one, only partially successful at counteracting the dominant rhetoric of barrenness and loss. Even so, the writings of Carey suggest that despite primogeniture and the supposedly rigid patrilineal 
economy in seventeenth-century England, genealogies could sometimes be understood as plural, divergent, or temporally diffuse-bound up not only with the local, legal stories of individual families but also with the "large story" implied by Protestant historiography. 
Copyright of Modern Philology is the property of University of Chicago Press and its content may not be copied or emailed to multiple sites or posted to a listserv without the copyright holder's express written permission. However, users may print, download, or email articles for individual use. 